\title{
Institutional, gender and racial profiles of South African optometrists
}

\author{
U Nirghin $^{a}$, N Ebrahim Khan ${ }^{b}$ and KP Mashigec
}

a, b, c Discipline of Optometry, School of Physiotherapy, Sport Science and Optometry, Faculty of Health Sciences, University of KwaZulu-Natal, Westville Campus, Private Bag X54001, Durban, 4000 South Africa

$<$ nirghinu@ukzn.ac.za>

<ebrahimn@ukzn.ac.za>

$<$ mashigek@ukzn.ac.za>

Received 8 January 2011; revised version accepted 15 August 2011

\section{Abstract}

This paper sets out to profile optometric graduates in South Africa. The 2008 register of the Health Professions Council of South Africa (HPCSA) was used to identify the number of registered optometrists, their qualifications and institutions where they obtained their primary optometry qualification. The gender and racial profiles of these optometrists were obtained from the institutions where they qualified. A comparison of the profiles of the registered practitioners pre-democracy (19301994) and post-democracy (1995-2008) was made. Few $(28.1 \%)$ of the optometrists were trained in the years 1930-1994, while the rest $(71.9 \%)$ were trained from 1995-2008. During the period of $1930-1994,64.2 \%$ of the optometrists were males and $35.8 \%$ were females and from 1995 to 2008 , the gender profile changed to $66.4 \%$ females and $33.6 \%$ males. In the pre-democracy period (1930$1994)$, almost three quarters $(74 \%)$ of the registered optometrists were White, $15.3 \%$ were Indians, $7.9 \%$ were Black and $2.8 \%$ were Coloured. Many (56.9\%) that were registered pre-1994 were trained at the Technikon Witwatersrand (TWR), $17.1 \%$ were trained at the University of Durban Westville (UDW), $11.9 \%$ at the Rand Afrikaans
University (RAU), 6.7\% at the University of the North (UNIN) and $7.4 \%$ had trained in institutions outside South Africa. The percentage of White optometrists post-democracy (1995-2008) decreased to $44.3 \%$, while those of Indians increased to $22 \%$, Blacks increased to $28.9 \%$ and Coloured to $4.8 \%$. Almost half $(48.2 \%)$ of the optometrists in the post-apartheid era (1995-2008) were trained at the University of Johannesburg (UJ), TWR and RAU, $21.5 \%$ at UDW and University of KwaZulu-Natal (UKZN), 23.7\% at UNIN and the University of Limpopo (UL), 4\% at the University of Free State (UFS) and others $(2.6 \%)$ had trained outside South Africa. As at 2008, the majority (51.7\%) of all registered optometrists were White, 22.2\% were Black, $21.9 \%$ were Indian while $4.2 \%$ were Coloured and included $57.8 \%$ females and $42.2 \%$ males. The results of this study indicate that the number of females in all racial categories has increased post-democracy. Although the number of Black optometrists has increased in the postdemocracy era, the increase does not yet reflect the national population distribution. Optometry departments need to improve on the equity targets. (S Afr Optom 2011 70(3) 123-128)

Key words: Optometrists, race, gender, equity, optometry institutions

\footnotetext{
a BOptom(UDW)

b BOptom(UKZN)

${ }^{c}$ BSc(Wits) BOptom(UDW) CAS(NECO) MOptom(UKZN)
} 


\section{Introduction}

In South Africa, the first optometrists were registered with the South African Optometric Association (SAOA) in 19241. These optometrists were all educated in Britain ${ }^{1}$. The first formal training of optometrists in South Africa started in 1930 at the Witwatersrand Technical College ${ }^{1}$ (as it was then known). This training was reserved for white students only, thus reflecting the broader South African politics at that time. Also, during that time, major discrepancies existed in the access to higher education for many students in terms of race, gender, class and geographical location $^{2}$. However, there is now a greater degree of engagement with issues of equity and redress through providing institutional access.

Pre-1975, South African optometrists were trained by Technikon Witwatersrand (TWR) and the graduates of that institution were predominantly white ${ }^{3}$. In 1975, the University of the North (UNIN) started the optometry programme mainly to cater for blacks (Northern and Southern Sotho, Tsonga, Tswana, Venda and black students from the Southern African region) $)^{3}$. This was followed by the University of Durban Westville (UDW) in 1979, and by the Rand Afrikaans University (RAU) in $1985^{3}$. The University of Durban Westville catered to Indian students and RAU was reserved mainly for white Afrikaans speaking students ${ }^{3}$.

One of the initiatives taken by the post-apartheid government was to develop legislative and policy tools aimed at transforming the higher education system $^{4}$. These initiatives included accelerated expansion of and increased access to higher education through affirmative action policies for under-represented groups. Also, increased access to and equitable allocation of financial resources such as the National Student Financial Aid Scheme of South Africa (NSFAS) aimed at supporting previously disadvantaged students. The government monitors these equity processes at institutions through audits commissioned by the Centre of Higher Education (CHE) and evaluations by the statutory professional bodies such as the HPCSA. This concept emanated from the reality of a racially-segregated system of higher education with white, urban institutions intrinsically linked to the economic development of the country and therefore well funded, and black, rural institutions linked to the old Bantustan system which were therefore poorly resourced $^{4}$. In 2001, the Minister of Education appointed a national working group to advise him on restructuring the institutional landscape of the higher education system ${ }^{5}$. This process resulted in changes in academic structures which saw the mergers of institutions in the country, with optometry being affected by these mergers. The University of Limpopo (UL) was formed from the merger of the Medical University of South Africa (MEDUNSA) and UNIN, University of Johannesburg (UJ) from TWR and RAU, University of KwaZulu-Natal (UKZN) from UDW and University of Natal (UN). Another institution, the University of Free State (UFS), started an optometry programme in 2002 to provide further access to South Africans who wish to study optometry6.

Optometric education is currently offered at these four higher education institutions in South Africa. These higher institutions now accept students of all races. However, it is not widely known what proportion of the optometric workforce is produced by each of these institutions in terms of gender and racial profiles. Information from this study will be beneficial in aligning academic education with variables such as gender, race and the need to increase intake by some institutions. Like so many areas of South African life, the need for redress and equity is a pressing one $^{7}$. While there have been attempts to transform the health care profession especially its training and selection of students, these have been rather slow off the mark. They have also failed to gather the momentum required within the broader context of the profession, its numbers, the national eye health service needs, the country's political developments and its equity legislation ${ }^{8}$. It must be borne in mind that there are factors other than institutional challenges that contribute to the current state of inequity in health care professions $^{8}$. Some of these can be located within the primary and secondary education sectors, and especially those in disadvantaged and rural communities ${ }^{9}$. Reddy ${ }^{10}$ in 2000 noted that the abundance of poorly resourced, secondary schools results in ill-prepared students entering the tertiary education arena and under-performing.

Lalloo et a ${ }^{11}$ in 2005 profiled the dental graduates and students of South Africa to compare pre- and post democracy profiles. The study showed that there was an increase from $21 \%$ to $46 \%$ in female dental graduates from pre-democracy to post 1994 . In addition, 
there was a decrease in the number of dental graduates between the two periods (from $78 \%$ to $46 \%$ ). A study by Cleaton-Jones et al 12 in 1996 profiled the demographics of the University of the Witwatersrand (Wits) dental graduates from 1927-1995. The results showed that $6 \%$ of the total dental graduates were female and only $7 \%$ were Black, Indian, Chinese or Coloured. The study by Dambisya et al ${ }^{13}$, in 2005 profiled black pharmacy graduates at UL and found that of the 121 respondents, $55 \%$ were males and $45 \%$ were females. Hence, this study aims to investigate the profile of the South African optometric workforce in terms of their gender, race, qualifications and institutions where they qualified.

\section{Methodology}

Permission to conduct the study was obtained from the Biomedical Research and Ethics Committee of the Faculty of Health Sciences, University of KwaZulu-Natal. Records of the 2936 optometrists who were registered with the HPCSA in 2008 were examined and data relating to qualification and institution of training was extracted. However, the register does not list the gender and race groups of optometrists. Therefore, the various universities were approached for the information on the gender and race profiles for all those optometrists who qualified locally. Also, the gender and race profiles of the small number of optometrists who were registered with the HPCSA but qualified outside South Africa were obtained through personal knowledge and contacts. The composite data from these two searches were analyzed using the Statistical Package for Social Sciences (SPSS version 15.0).

\section{Results}

Of the optometrists that were trained in the predemocracy period, $35.8 \%$ were females and $64.2 \%$ were males and their racial profile was as follows: $74 \%$ White, $15.3 \%$ Indian, $7.9 \%$ Black and $2.8 \%$ Coloured. The distribution of institutions where optometrists were trained in relation to their gender and race, pre-democracy is presented in Table 1 below.

Those that were registered post-democracy com-

Table 1: Number and percentage of registered optometrists pre-democracy (1930-1994) by gender, racial group and institution. Other in the table refers to those who qualified outside South Africa.

\begin{tabular}{|l|l|l|l|l|l|l|l|}
\hline \multirow{2}{*}{} & \multicolumn{2}{|c|}{ GENDER } & \multicolumn{4}{c|}{ RACE } & \multirow{2}{*}{$\begin{array}{l}\text { Total } \\
\text { INSTITUTION }\end{array}$} \\
\cline { 2 - 7 } & $\begin{array}{l}\text { Male } \\
\mathrm{N}(\%)\end{array}$ & $\begin{array}{l}\text { Female } \\
\mathrm{N}(\%)\end{array}$ & $\begin{array}{l}\text { Coloured } \\
\mathrm{N}(\%)\end{array}$ & $\begin{array}{l}\text { Black } \\
\mathrm{N}(\%)\end{array}$ & $\begin{array}{l}\text { Indian } \\
\mathrm{N}(\%)\end{array}$ & $\begin{array}{l}\text { White } \\
\mathrm{N}(\%)\end{array}$ & \\
\hline TWR & $342(72.7 \%)$ & $128(27.2 \%)$ & $10(2.1 \%)$ & $7(1.5 \%)$ & $8(1.7 \%)$ & $445(94.7 \%)$ & 470 \\
\hline RAU & $43(43.9 \%)$ & $55(56.1 \%)$ & $5(5.1 \%)$ & $1(1 \%)$ & $0(0 \%)$ & $92(93.9 \%)$ & 98 \\
\hline UDW & $57(40.4 \%)$ & $84(59.6 \%)$ & $6(4.3 \%)$ & $3(2.1 \%)$ & $106(75.2 \%)$ & $26(18.4 \%)$ & 141 \\
\hline UNIN & $38(68 \%)$ & $18(32 \%)$ & $1(1.8 \%)$ & $54(96.4 \%)$ & $1(1.8 \%)$ & $0(0 \%)$ & 56 \\
\hline Other & $50(82 \%)$ & $11(18 \%)$ & $1(1.6 \%)$ & $0(0 \%)$ & $12(19.6 \%)$ & $48(78.7 \%)$ & 61 \\
\hline Total & $530(64.2 \%)$ & $296(35.8 \%)$ & $23(2.8 \%)$ & $65(7.9 \%)$ & $127(15.3 \%)$ & $611(74 \%)$ & 826 \\
\hline
\end{tabular}

Table 2: Number and percentage of registered optometrists post-democracy (1995-2008) by gender, racial group and institution. Other refers to those who qualified outside South Africa.

\begin{tabular}{|c|c|c|c|c|c|c|c|}
\hline \multirow[t]{3}{*}{ INSTITUTION } & \multicolumn{2}{|l|}{ GENDER } & \multicolumn{4}{|l|}{ RACE } & \multirow{3}{*}{$\begin{array}{l}\text { Total } \\
\mathrm{N}\end{array}$} \\
\hline & Male & Female & Coloured & Black & Indian & White & \\
\hline & $\mathrm{N}(\%)$ & $\mathrm{N}(\%)$ & $N(\%)$ & $N(\%)$ & $N(\%)$ & $N(\%)$ & \\
\hline TWR, RAU \& UJ & $309(30.1 \%)$ & $708(69.6 \%)$ & $68(6.7 \%)$ & $48(4.7 \%)$ & $116(16.3 \%)$ & $785(72.3 \%)$ & 1017 \\
\hline UDW \& UKZN & $154(34.1 \%)$ & $298(65.9 \%)$ & $11(2.4 \%)$ & $89(19.7 \%)$ & $311(68.8 \%)$ & $41(9 \%)$ & 452 \\
\hline UNIN \& UL & $184(36.7 \%)$ & $317(63.3 \%)$ & $9(1.8 \%)$ & $457(91 \%)$ & $29(5.8 \%)$ & $6(1.2 \%)$ & 501 \\
\hline UFS & $22(25.9 \%)$ & $63(74.1 \%)$ & $7(8.2 \%)$ & $9(10 \%)$ & $3(3.5 \%)$ & $66(77.7 \%)$ & 85 \\
\hline Other & $41(74.5 \%)$ & $14(25.5 \%)$ & $6(10.9 \%)$ & $7(12.7 \%)$ & $6(10.9 \%)$ & $36(65.5 \%)$ & 55 \\
\hline Total & $710(33.6 \%)$ & $1400(66.4 \%)$ & $101(4.8 \%)$ & $610(28.9 \%)$ & $465(22 \%)$ & $934(44.3 \%)$ & 2110 \\
\hline
\end{tabular}


prised of $66.4 \%$ females and $33.6 \%$ males while their racial breakdown was $44.3 \%$ White, $28.9 \%$ Black, $22 \%$ Indian and $4.8 \%$ Coloured (Table 2).

As at 2008, there were 2936 optometrists registered with the HPCSA. The majority, $(57.8 \%)$ were female and $(42.2 \%)$ were male. More than half $(57.5 \%)$ of the optometrists were trained at the historically (White) institutions. Of these, $80.3 \%$ were White, $10.5 \%$ were Indian, 5.3\% were Coloured while $3.9 \%$ were Black and included $59.5 \%$ females and $40.5 \%$ males. In total, the historically non-white universities trained $38.3 \%$ of registered optometrists. These included 51.3\% Blacks, 6.5\% Whites, 39.7\% Indians and 2.5\% Coloureds. Females (58.3\%) were the dominant gender. Others $(4.2 \%)$ had received their training outside South Africa, the majority of whom were $(73.8 \%)$ and male $(76.2 \%)$. The distribution of institutions where optometrists obtained their qualifications in relation to their gender and race is illustrated in Figures 1 and 2 respectively.

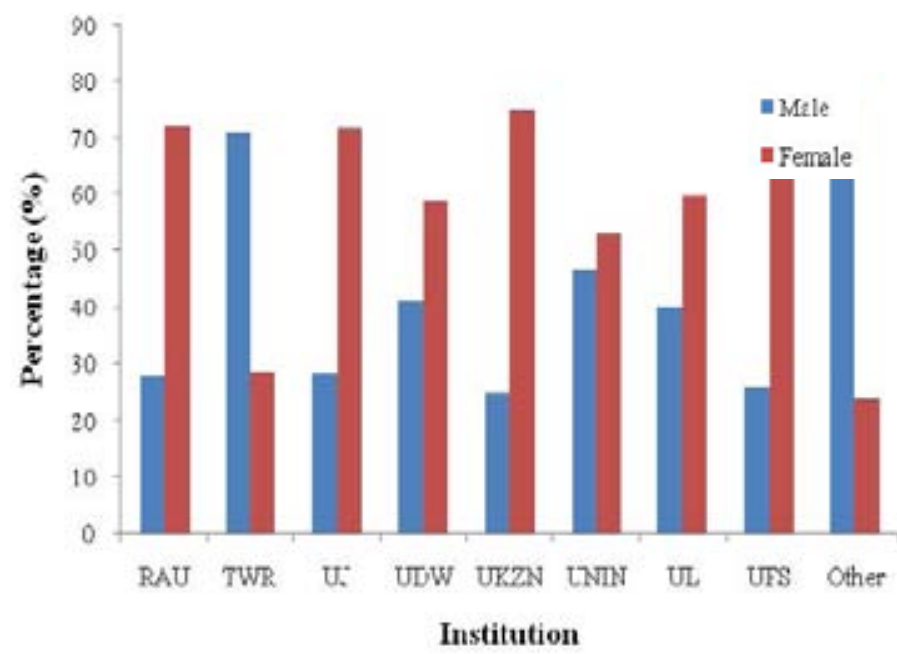

Figure 1: Percentages of registered optometrists (2008) by gender and institution of qualification. Other in the figure refers to those institutions outside South Africa.

There were 51.7\% Whites, 22.1\% Blacks, 21.9\% Indians, and $4.3 \%$ Coloureds. Overall, $29.2 \%$ of the optometrists obtained their primary qualifications from RAU, followed by TWR (16.6\%), the majority being females. The majority, $(77.3 \%)$ were registered with the HPCSA with the Bachelor of Optometry (BOptom) degree as their primary qualification, $21.3 \%$ had the Diploma of Optometry qualification, $0.1 \%$ had the Doctor of Optometry (OD) degree and others $(1.3 \%)$ had completed the bridging course in optometry undertaken by dispensing opticians to enable them to work as optometrists. Women were the dominant gender in the three main qualification categories.

$m$ Colcured

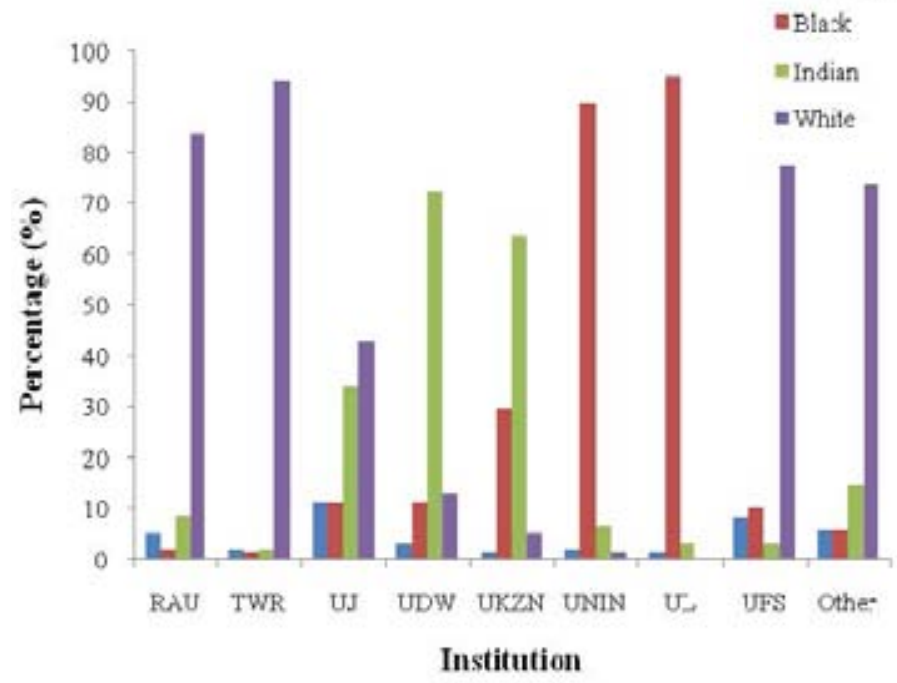

Figure 2: Percentages of registered optometrists (2008) by racial group and institution of qualification. Other refers to institutions outside South Africa.

\section{Discussion}

The eye care sector faces a number of challenges; among these is the problem of securing a reliable supply of trained workers with diverse gender and racial equity representations. Gender and racial equity have social implications and affects the distribution of optometric services. For example, males are generally not averse to venturing out to various areas to practice the profession as compared to their female counterparts. Black optometry graduates are also more likely, than graduates of other race groups, to work in black areas which are often underserved and rural. Also, in general, Black graduates are more likely to practice in the public sector and less likely to emigrate 7 . The gender profile pre-democracy (pre-1994) was 64.2\% males and $35.8 \%$ females, which changed to $33.6 \%$ males and $66.4 \%$ females in the post-democracy period. Thirteen years after the end of apartheid (2008), it is interesting and important to note that the gender profile was $57.8 \%$ females and $42.2 \%$ males. This gender-shift could either be due to the females having more interest in optometry or they had better grades than the males, hence were given preference in the admission process ${ }^{14,15}$ or the males preferring professions outside health sciences. Pre-democracy, majority $(56.9 \%)$ of the graduates were from TWR. This is 
because TWR was the only optometry programme ${ }^{3}$ in South Africa from 1930 to 1975. Therefore, TWR historically provided the training ground for many of South Africa's optometrists and optometric educators. This programme, which awarded a diploma, has been phased out because of the four year degree programme now in existence.

The racial profile in this study does not yet reflect the distribution of the national population, with Blacks and Coloureds being under-represented. The national census of 2001 showed that $79 \%$ of the total population was Black, 9.6\% White, $8.9 \%$ Coloured and $2.5 \%$ Indian $^{16}$. This could be explained by the fact that in the past, optometry departments at institutions were established to train optometrists along racial groups, and thus the demographic profile clearly reflects this apartheid-era legacy of past political legislations. For example, since its inception in 1975 until 1991, the student population at UNIN was exclusively Black ${ }^{17}$ while RAU and TWR accepted mainly White students during the pre-democracy period ${ }^{18}$. The University of Durban Westville produced predominantly Indian graduates. This therefore reflects the racial divisions enforced by the apartheid system. Improving racial diversity should improve access to eye care for underserved patients and thus has an important role in deciding public policy. Of interest, however, is that in the post-democracy period, the racial distribution of graduates increased by $2 \%$ for Coloureds, $21 \%$ for Blacks, Indians increased by about $7 \%$ of graduates while Whites decreased by about $30 \%$. An analysis of the breakdown of training institutions showed that traditionally White institutions, were still producing majority White graduates and traditionally Black universities were still graduating the majority of Blacks 13 years after the end of apartheid. For example, UNIN and UL respectively trained $89.8 \%$ and $95.1 \%$ of Black optometrists registered at the time of this investigation. On the other hand, UJ and UFS trained $43.2 \%$ and $77.6 \%$ of White optometrists respectively. However, UJ appear to have made a positive impact on the number of Indian optometrists trained in the country. This suggests the need to attract, recruit and retain talented Black students to historically White institutions and White students to historically Black institutions. However, while there has generally been a decline in White graduates from historically White institutions, more Blacks have graduated from these institutions than during the apartheid era. This could be attributed to the higher number of Black students enrolling in historically-advantaged White institutions due to better resources and perceived prestige of these institutions ${ }^{19}$.

There are a number of challenges such as the decline in the number of Black students who obtain matric exemption ${ }^{20}$. Therefore, the low number of Black optometry graduates is exacerbated by the poor supply of Black students to universities ${ }^{20}$. Furthermore, the students are not leaving school with either appropriate subjects in science or are producing grades that are too low to qualify for entry into tertiary institutions, which hinders recruitment efforts ${ }^{20}$. Statistics show that only $41 \%$ of Black pupils passed the matriculation examinations in 1991 and only $11 \%$ of those obtained a matriculation exemption ${ }^{14}$. On the contrary, $95 \%$ of White pupils who wrote matric in 1991 passed and $42 \%$ of them gained matriculation exemption ${ }^{14}$. Although the pass rates of Black pupils in 2006 increased to $62 \%$, the matriculation exemption rate was only $11.6 \%$ while the matriculation exemption rate of White pupils increased to $52 \%$ in the similar year ${ }^{14}$. Furthermore, only $2.3 \%$ of the Black pupils who wrote the 2006 examinations, passed mathematics at higher grade ${ }^{14}$. This means that as education for Black South Africans under apartheid was inferior, little progress if any has been made since apartheid ended.

The fact that there are generally few Coloured optometrists could be explained by the fact that the majority of Coloureds are in the Western Cape, where no optometry department exists. Also, there are generally few coloureds registered in optometric programmes in South Africa ${ }^{15}$. We therefore recommend to the government that the Cape Peninsula University of Technology (CPUT), which offers the Dispensing programme be upgraded to include Optometry or the University of Cape Town should start an optometry programme. We also recommend that the HPCSA register should include gender and race for future use of researchers.

\section{Conclusion}

Relative to the national demography, there are more female optometrists in South Africa. Also, White and Indian optometrists are over-represented while Blacks and Coloureds are under-represented. 
Therefore, the current nation's optometric workforce does not reflect the diversity of the nation. South African optometric institutions will need to accelerate and increase access for previously under-represented groups in order to align themselves with the broader national priorities of achieving equity and redress.

\section{Acknowledgements}

The authors would like to acknowledge all the institutions that provided valuable demographic information on their alumni.

\section{References}

1. Ferreira JT. The development and practice of optometry in South Africa. S Afr Optom 199352 56-60.

2. Morrel R. Power and politics at a non-racial, ethnic university: A case study of the University of Durban Westville. Clin Arts 19915 49-77.

3. Oduntan AO. Thirty years of optometric education at Turfloop (1975-2005): A historical and educational overview. $S$ Afr Optom $2006 \mathbf{6 5}$ 34-40.

4. Department of Education. Transformation and Restructuring: A New Institutional Landscape for Higher Education, Government of South Africa, Pretoria, 2002.

5. Department of Education. The Restructuring of the Higher Education System in South Africa: Report of the National Working Group to the Minister of Education, Government of South Africa, Pretoria. White paper on Higher Education Transformation, Government of South Africa, Pretoria, $2001 b$.

6. Oduntan AO, Louw A, Moodley VR, Richter M, Von Poser P. Perceptions, expectations, apprehensions and realities of graduating South African optometry students (PEAR study, 2006). S Afr Optom 200766 94-108.

7. Ahmed R, Pillay AL. Reviewing clinical psychology training in the post-apartheid period: Have we made any progress? SAJP 200434 630-656.

8. Akoojee S, Nkomo M. Access and quality in South African higher education: the twin challenges of transformation. $S A$ JHE 200721 385-399.

9. Ramrathan P, Manik S, Pillay G. Transformational access: The Upward Bound Programme as a possibility for promoting access to Higher Education. SAJHE 200721 733-752.

10. Reddy J. Regional consortia, partnerships, mergers and implications for the transformation of the South African higher education system. SAJHE 200014 79-87.

11. Lalloo R, McMillan W, Gugushe TS, Ligthelm AJ, Moola $\mathrm{MH}$. Gender and race distribution of dental graduates (19852004) and first year dental students (2000-2005) in South Africa. SADJ 200560 206-209.

12. Cleaton-Jones P, Volchansky A, Copland L. Epidemiological profile of graduates of the Wits Dental faculty 1927-1995. J
Dent Assoc S Afr 199651 721-725.

13. Dambisya Y, Modipa IS, Legodi M. The Distribution of Pharmacists Trained at the University of the North, South Africa. Report submitted to the Regional network for equity in health in East and Southern Africa (EQUINET), November 2005.

14. Department of Education and Independent Examination Board Report. The Matric Results by Race and Other Categories, 2006.

15. Mashige KP, Oduntan OA. Factors influencing South African optometry students in choosing their career and institution of learning. S Afr Optom 201170 21-28.

16. Statistics South Africa. The People of South Africa Population Census. Report number 03-02-03. Statistics South Africa: Pretoria, 2001.

17. Gowans M. Optometry at Turfloop. S Afr Optom 199150 125-129.

18. Penisten DK. Optometry and optometric education in Africa past, present and future. S Afr Optom 199251 161-171.

19. Department of Education. National Plan on Higher Education in South Africa. Government Printers, Pretoria, 2001.

20. Ntshoe IM. The political economy of access and equitable allocation of resources to higher education. Int $J E d u c$ Dev 200323 381-398. 